Henryk Dzwonkowski

\title{
Prawnofinansowa ocena art. 25 ustawy o finansowaniu zadań oświatowych ${ }^{1}$
}

\begin{abstract}
Legal and financial evaluation of Article 25 of the Act on Financing of Educational Tasks: As a consequence of the solution provided by Article. 25 of the Act and solutions planned at the level of the Regulation on the manner of dividing the educational part of the general subsidy for local government units in 2018, the previous subsidy calculated with consideration of the number students of particular types of schools (including general secondary schools for adults, post-secondary schools) has been divided into two parts: "for participation in classes", which is unconditional and "for passed exam", which is conditional and depends on the effectiveness of education. This solution implements a postulate of the Supreme Chamber of Control. As a result of the adopted solutions in case of schools with low level of passing of exams, a subsidy applied to them will be lower than before. Finally, there may be a significant reduction in the amounts of subsidies concerning to adult students in relation to the current level. If the new solution is not neutral for subsidized institutions, violations of the rule of equal treatment of entities running educational institutions may occur.
\end{abstract}

\author{
Keywords: $\quad$ subsidies | education | public finance | constitution | education | \\ local self-government | school \\ Słowa kluczowe: dotacje | edukacja | finanse publiczne | konstytucja | oświata | \\ samorząd terytorialny | szkoła
}

Doktor hab. nauk prawnych, profesor Uniwersytetu Łódzkiego; hdzwonkowski@poltax.pl.

\section{Przedmiot opinii}

Do Marszałka Sejmu RP wpłynęło pismo dyrektor Publicznej Zaocznej Policealnej Szkoły Informatyki Cosinus w Łodzi z 27 października 2017 r., w którym

1 Opinia prawna w przedmiocie prawnofinansowej oceny przepisów art. 25 ustawy o finansowaniu zadań oświatowych wyznaczających zasady otrzymywania dotacji przez podmioty prowadzace szkołe publiczna niebędace jednostka samorzadu terytorialnego sporządzona 30 listopada 2017 r. na zlecenie zastępcy Szefa Kancelarii Sejmu; BAS-WASiE 2293/17. 
zwrócono uwagę, że zaproponowane w projekcie ustawy o finansowaniu zadań oświatowych regulacje wprowadzają różne traktowanie szkół publicznych w zależności od tego, kto jest organem prowadzącym placówki oświatowej. Autorka pisma argumentuje, że nieuzasadnione jest wprowadzanie odmiennych zasad dotowania szkół w zależności od tego, czy organem prowadzącym jest jednostka samorządu terytorialnego czy też inny podmiot, bowiem nie ma to znaczenia dla wysokości kosztów organizacji nauki w szkołach. Dodatkowo wskazała, że koszty utrzymania jednego słuchacza w szkole prowadzonej przez jednostki samorządu terytorialnego czy przez inne podmioty nie różnią się od siebie. Stąd - zdaniem autorki pisma - przewidziane w art. 25 projektu zasady dotowania szkół prowadzonych przez podmioty niebędące jednostkami samorządu terytorialnego wprowadzają dyskryminację tych podmiotów. Uzasadnienie projektu ustawy nie wyjaśnia, dlaczego zaproponowane zostało takie rozróżnienie.

\section{Analiza prawna zagadnienia}

Przystępując do analizy przedstawionego zagadnienia, w pierwszej kolejności należy poczynić kilka uwag natury ogólnej, które warunkują prawidłowe ustalenia co do oceny prawnofinansowej wskazanych przepisów ustawy o finansowaniu zadań oświatowych ${ }^{2}$.

Finansowanie oświaty stanowi, zgodnie z obowiązującym systemem prawnym $^{3}$, zadanie własne jednostek samorządu terytorialnego i jest realizowane ze środków własnych samorządów oraz z subwencji oświatowej przekazywanej z budżetu państwa. Algorytm podziału łącznej kwoty części oświatowej subwencji ogólnej (pomniejszonej o kwotę rezerwy), zawartej w ustawie budżetowej, między poszczególne jednostki samorządu terytorialnego wszystkich szczebli jest ustalany corocznie w postaci określonego wzoru matematycznego i publikowany w rozporządzeniu ministra właściwego do spraw oświaty i wychowania (Minister Edukacji Narodowej) $)^{4}$. Według ogólnej dyrektywy podziału zawartej w art. 28 ust. 5 ustawy o dochodach jednostek samorządu terytorialnego dokonuje się, biorąc pod uwagę zakres realizowanych przez jednostki samorządu terytorialnego zadań oświatowych, z wyłączeniem zadań związanych z dowozem uczniów oraz zapewnieniem kształcenia, wychowania i opieki uczniom, którzy

2 Ustawa z 27 października 2017 r., która w dniu 13 listopada 2017 r. została przekazana Prezydentowi RP do podpisu.

3 Ustawa z 7 września 1991 r. o systemie oświaty (t.j. Dz.U. 2016, poz. 1943, ze zm.); ustawa z 14 grudnia 2016 r. - Prawo oświatowe (Dz.U. 2017, poz. 59, ze zm.); ustawa z 13 listopada 2003 r. o dochodach jednostek samorządu terytorialnego (t.j. Dz.U. 2017, poz. 1453).

4 Zob. art. 28 ust. 6 ustawy z 13 listopada 2003 r. o dochodach jednostek samorządu terytorialnego, Dz.U. 2017, poz. 1453, ze zm. 
kończą 5 lat lub mniej w roku bazowym, w przedszkolach, oddziałach przedszkolnych w szkołach podstawowych i innych formach wychowania przedszkolnego, niezwiązanych $z$ wychowaniem i kształceniem specjalnym albo zajęciami rewalidacyjno-wychowawczymi. Sposób podziału określony przez ministra powinien uwzględniać w szczególności:

- typ i rodzaj szkół i placówek prowadzonych przez te jednostki,

- stopień awansu zawodowego nauczycieli,

- liczbę uczniów w szkołach i placówkach,

- liczbę dzieci, które ukończyły 6 lat lub więcej w roku bazowym, objętych wychowaniem przedszkolnym w przedszkolach, oddziałach przedszkolnych w szkołach podstawowych i innych formach wychowania przedszkolnego,

- zróżnicowania kwot ustalanych na dzieci objęte wychowaniem przedszkolnym i dzieci realizujące obowiązek szkolny i obowiązek nauki z uwzględnieniem wyższej kwoty na dziecko objęte wychowaniem przedszkolnym w przedszkolach oraz wyższej kwoty w przedszkolach, oddziałach przedszkolnych w szkołach podstawowych i innych formach wychowania przedszkolnego zlokalizowanych na terenach wiejskich i w miastach do 5000 mieszkańców.

Warto zauważyć, że w świetle obowiązujących regulacji nie ma jednak bezpośredniego związku między naliczaną częścią oświatową subwencji ogólnej a wydatkami samorządowymi na oświatę, a kwestia adekwatności środków otrzymywanych w formie subwencji oświatowej w stosunku do realizowanych zadań oświatowych bywa oceniana krytycznie przez jednostki samorządu terytorialnego.

Należy również zwrócić uwagę, że szkoły oraz placówki oświatowe mogą być zakładane i prowadzone zarówno przez ministrów i jednostki samorządu terytorialnego, jak i przez osoby prawne niebędące jednostkami samorządu terytorialnego lub osoby fizyczne (art. 8 ust. 2 ustawy - Prawo oświatowe). Przedszkola, szkoły i placówki publiczne zakładane i prowadzone przez ministrów i jednostki samorządu terytorialnego są jednostkami budżetowymi. Zasady gospodarki finansowej tych placówek określają odrębne przepisy (art. 79 ustawy o systemie oświaty), w tym przede wszystkim ustawa z 27 sierpnia 2009 r. o finansach publicznych (t.j. Dz.U. 2017, poz. 2077, ze zm.) oraz rozporządzenie Ministra Finansów z 7 grudnia 2010 r. w sprawie sposobu prowadzenia gospodarki finansowej jednostek budżetowych i samorządowych zakładów budżetowych (t.j. Dz.U. 2015, poz. 1542). Fakt, że szkoły i placówki prowadzone przez podmioty prawa publicznego mają obligatoryjnie formę organizacyjno-prawną tzw. jednostek budżetowych (art. 11 ustawy o finansach publicznych), skutkuje tym, że prowadzą one najmniej samodzielną formę gospodarki. Zarówno bowiem z prawnofinansowego, jak i z ekonomicznego punktu widzenia jednostka budżetowa jest nierozerwalnie powiązana $\mathrm{z}$ budżetem państwa lub budżetem jednostki samorządowej. Jako jednostki budżetowe placówki te są zatem utrzymywane w zasadzie wyłącz- 
nie ze środków budżetowych. Ograniczenie ich samodzielności wyraża się w tzw. zasadzie budżetowania brutto, w myśl której całość dochodów jednostki budżetowej jest pokrywana bezpośrednio z budżetu macierzystego, a całość pobranych dochodów jest odprowadzana na rachunek dochodów budżetu.

Obowiązek finansowania szkół i placówek oświatowych prowadzonych przez jednostki samorządu terytorialnego spoczywa na tych jednostkach. W finansowaniu tym ma swój udział całość dochodów uzyskiwanych przez jednostki samorządu terytorialnego, tj. obok części oświatowej subwencji ogólnej również pozostałe dochody. Część oświatowa nie może być tym samym wyłącznym punktem odniesienia dla wysokości nakładów przeznaczanych przez jednostki samorządu terytorialnego na konkretne zadania oświatowe. Co więcej, jakkolwiek część oświatowa jest naliczana na podstawie m.in. typu i rodzaju szkół i placówek oświatowych prowadzonych przez jednostki samorządu terytorialnego oraz liczby uczniów w tych szkołach i placówkach, to w praktyce środki naliczone na uczniów określonej jednostki oświatowej nie muszą być przeznaczone na realizację zadań oświatowych przez tę jednostkę adekwatnie do przeprowadzonych wyliczeń. W myśl bowiem art. 7 ustawy o dochodach jednostek samorządu terytorialnego o przeznaczeniu środków otrzymanych z tytułu subwencji ogólnej decyduje organ stanowiący jednostki samorządu terytorialnego. Innymi słowy, źródłem pochodzenia środków, z których finansowane są szkoły i placówki oświatowe prowadzone przez jednostkę samorządu terytorialnego, jest m.in. część oświatowa subwencji ogólnej, jednak kwota środków wydatkowana z budżetu tej jednostki na poszczególne jednostki oświatowe nie musi być równa kwocie subwencji oświatowej naliczonej na uczniów tej jednostki oświatowej.

Z oczywistych względów pozostałe placówki oświatowe, tj. te, które nie są zakładane i prowadzone przez ministrów i jednostki samorządu terytorialnego (zarówno mające charakter publiczny, jak i niepubliczny), nie są jednostkami budżetowymi, a zatem również i forma finansowania ich działalności musi być odmienna. Jak wskazuje art. 80 ust. 1 ustawy o systemie oświaty, przedszkola, szkoły i placówki publiczne niewymienione w art. 79 (a więc niebędące jednostkami budżetowymi) prowadzą gospodarkę finansową według zasad określonych przez organ lub podmiot prowadzący szkołę.

Biorąc zatem pod uwagę fakt, że w przeciwieństwie do jednostek prowadzonych przez samorząd placówki oświatowe publiczne niebędące jednostkami budżetowymi (takie jak Publiczna Zaoczna Policealna Szkoła Informatyki Cosinus z Łodzi, której dyrekcja zgłosiła zastrzeżenia do projektu ustawy o finansowaniu zadań oświatowych), nie są wprost powiązane z budżetem samorządu terytorialnego, funkcjonuje obecnie system dotacji, który służy dofinansowaniu realizacji zadań szkół lub placówek oświatowych prowadzonych przez osoby prawne

Zob. Z. Pirożyński, Budżetowanie brutto [w:] Leksykon finansowo-bankowy, red. W. Jaworski, Warszawa 1991, s. 59. 
niebędące jednostkami samorządu terytorialnego lub osoby fizyczne w zakresie kształcenia, wychowania i opieki, w tym kształcenia specjalnego i profilaktyki społecznej. U podstaw przyznawania tych dotacji leży założenie, że działalność oświatowa, jako mająca charakter niegospodarczy, jest z założenia deficytowa i, aby była prowadzona, wymaga wsparcia ze środków publicznych. Przyznanie dotacji następuje więc nie ze względu na doraźne zaspokojenie potrzeb finansowych podmiotu, ale aby systematycznie wyrównać bilans przychodów i kosztów działalności ${ }^{6}$. Dotacje te mogą być jednak wykorzystane wyłącznie na:

- pokrycie wydatków bieżących, obejmujących każdy wydatek poniesiony na cele działalności szkoły lub placówki oświatowej, w tym na: wynagrodzenie osoby fizycznej prowadzącej szkołę lub placówkę, jeżeli pełni funkcję jej dyrektora, sfinansowanie wydatków związanych z realizacją zadań organu prowadzącego ( $\mathrm{z}$ wyjątkiem wydatków na inwestycje i zakupy inwestycyjne, zakup i objęcie akcji i udziałów lub wniesienie wkładów do spółek prawa handlowego),

- zakup środków trwałych oraz wartości niematerialnych i prawnych, obejmujących: książki i inne zbiory biblioteczne, środki dydaktyczne służące procesowi dydaktyczno-wychowawczemu realizowanemu w szkołach, przedszkolach i placówkach, sprzęt rekreacyjny i sportowy, meble oraz pozostałe środki trwałe, wartości niematerialne i prawne o wartości nieprzekraczającej wielkości ustalonej w przepisach o podatku dochodowym od osób prawnych, dla których odpisy amortyzacyjne są uznawane za koszt uzyskania przychodu w 100\% ich wartości, w momencie oddania do używania.

W przypadku placówek publicznych, w których nie jest realizowany obowiązek szkolny lub obowiązek nauki (takich jak szkoły policealne), zastosowanie ma norma $\mathrm{z}$ art. 80 ust. 3ae ustawy o systemie oświaty, zgodnie z którą prowadzone przez osoby prawne niebędące jednostkami samorządu terytorialnego lub osoby fizyczne publiczne szkoły otrzymują na każdego ucznia dotację z budżetu jednostki samorządu terytorialnego obowiązanej do prowadzenia danego typu i rodzaju szkół w wysokości równej podstawowej kwocie dotacji dla szkół danego typu i rodzaju, nie niższej jednak niż kwota przewidziana na takiego ucznia w części oświatowej subwencji ogólnej dla jednostki samorządu terytorialnego. W przypadku braku na terenie odpowiednio gminy lub powiatu szkoły danego typu i rodzaju prowadzonej odpowiednio przez gminę lub powiat kwotę dotacji określa się w wysokości nie niższej niż kwota przewidziana na takiego ucznia w części oświatowej subwencji ogólnej odpowiednio dla gminy lub powiatu.

Biorąc pod uwagę powyższe uwarunkowania prawne, łatwo zauważyć, że obowiązujący dotąd system finansowania realizacji zadań oświatowych, w tym

6 Zob. M. Pilich, Ustawa o systemie oświaty. Komentarz, 2015, LEX, komentarz do art. 80 . 
w odniesieniu do placówek publicznych prowadzonych przez podmiot niebędący jednostką samorządu terytorialnego, z uwagi na swoje skomplikowanie oraz niejasność sformułowań budził wiele problemów związanych z jego stosowaniem (w tym m.in. dotyczących „poszukiwania” zbliżonej co do typu i rodzaju placówki oświatowej celem określenia prawidłowej wysokości dotacji). Warto przy tym podkreślić, że dotychczasowy sposób przyznawania dotacji doprowadził również do wytworzenia się niejednolitych praktyk w skali kraju oraz stanowił zarzewie sporów między organami właściwymi do udzielania dotacji a podmiotami dotowanymi.

Stąd wynikające $\mathrm{z}$ treści nowego aktu prawnego, jakim jest projekt ustawy o finansowaniu zadań oświatowych, założenie dotyczące stworzenia spójnego i uporządkowanego, a przede wszystkim uproszczonego zbioru przepisów obejmującego system dotacji zasługuje na aprobatę, jednakże szczegółowe rozwiązanie przewidziane $\mathrm{w}$ art. 25 ustawy może budzić pewne wątpliwości.

Przechodząc do szczegółowej analizy proponowanych rozwiązań ustawowych, warto w pierwszej kolejności pochylić się nad przepisem nowej ustawy o finansowaniu zadań oświatowych, który budzi największe obiekcje autorki pisma z 27 października 2017 r., kierowanego do Marszałka Sejmu RP, tj. art. 25.

Zgodnie z uchwalonym brzmieniem normy art. 25 ust. 3 o finansowaniu zadań oświatowych, znajdującej się w polu szczególnego zainteresowania podmiotu kierującego policealną szkołą publiczną Cosinus, prowadzone przez osoby prawne niebędące jednostkami samorządu terytorialnego oraz osoby fizyczne publiczne szkoły, w których nie jest realizowany obowiązek szkolny lub obowiązek nauki (obejmujące również szkoły policealne na podstawie art. 2 pkt $30 \mathrm{o}$ finansowaniu zadań oświatowych), niebędące szkołami specjalnymi, otrzymują na każdego ucznia dotację z budżetu jednostki samorządu terytorialnego będącej dla tych szkół organem rejestrującym, w wysokości równej kwocie przewidzianej na takiego ucznia w części oświatowej subwencji ogólnej dla jednostki samorządu terytorialnego.

Jednocześnie, jak stanowi art. 25 ust. 5 o finansowaniu zadań oświatowych, prowadzone przez osoby prawne niebędące jednostkami samorządu terytorialnego oraz osoby fizyczne publiczne licea ogólnokształcące dla dorosłych i szkoły policealne niebędące szkołami specjalnymi otrzymują, niezależnie od dotacji, o której mowa w ust. 3, na każdego ucznia, niebędącego uczniem niepełnosprawnym, który uzyskał odpowiednio świadectwo dojrzałości lub dyplom potwierdzający kwalifikacje zawodowe, dotację z budżetu jednostki samorządu terytorialnego będącej dla tych szkół organem rejestrującym, w wysokości równej kwocie przewidzianej na takiego ucznia w części oświatowej subwencji ogólnej dla jednostki samorządu terytorialnego, pod warunkiem że organ prowadzący tę szkołę przedstawi zaświadczenie o uzyskaniu przez ucznia tej szkoły odpowiednio świadectwa dojrzałości lub dyplomu potwierdzającego kwalifikacje zawodowe w terminie 12 miesięcy od dnia, w którym uczeń ukończył tę szkołę (za- 
świadczenie wydaje niezwłocznie okręgowa komisja egzaminacyjna na wniosek organu prowadzącego szkołę).

Jak wynika z treści wskazanych unormowań, system dotacji z budżetu jednostki samorządu terytorialnego w przypadku podmiotów prowadzących publiczne szkoły policealne (takie jak Publiczna Zaoczna Policealna Szkoła Informatyki Cosinus w Łodzi), składał się będzie z dwóch odrębnych elementów (części):

- części „bezwarunkowej”, „obligatoryjnej” dotacji - należnej w każdym przypadku, w wysokości równej kwocie przewidzianej na ucznia w części oświatowej subwencji ogólnej,

- części „dodatkowej” dotacji - przyznawanej w zależności od spełnienia kryteriów ustawowych związanych z rezultatami (skutecznością) prowadzonej przez daną placówkę edukacji, również w wysokości równej kwocie przewidzianej na ucznia w części oświatowej subwencji ogólnej.

Nowe rozwiązanie polegające na przyznaniu części dotacji w powiązaniu z efektem w postaci uzyskania przez ucznia świadectwa dojrzałości lub dyplomu potwierdzającego kwalifikacje zawodowe wpłynie na zmianę w algorytmie podziału subwencji oświatowej. Innymi słowy, oznacza to, że część subwencji na ucznia szkoły dla dorosłych będzie naliczana tak jak obecnie (tj. na każdego ucznia), a część subwencji będzie naliczana po zdanym egzaminie (tj. na uczniów, którzy zdali egzamin). Jednocześnie warto zauważyć, że twórcy projektu ustawy uwzględnili założenia oparte na danych według Systemu Informacji Oświatowej (SIO) na dzień 30 września 2016 r. oraz przyjęli, że wskaźnik zdawalności w szkołach dla dorosłych w liceach ogólnokształcących wyniesie 15\%, a w szkołach policealnych dla dorosłych $50 \%$.

Uwzględnienie w algorytmie podziału części oświatowej subwencji ogólnej między poszczególne jednostki samorządu terytorialnego liczby uczniów, którzy zdali odpowiednio egzamin maturalny lub egzamin potwierdzający kwalifikacje w zawodzie w liceach ogólnokształcących dla dorosłych, szkołach policealnych oraz w szkołach lub placówkach prowadzących kwalifikacyjne kursy zawodowe, wprowadza zmiana do art. 28 ust. 5 ustawy o dochodach jednostek samorządu terytorialnego ujęta w art. 81 nowej ustawy o finansowaniu zadań oświatowych.

W ślad za zmianami regulacji w zakresie finansowania kształcenia dorosłych przyjętymi w ustawie o finansowaniu zadań oświatowych odpowiednie zmiany zostały zaproponowane w projekcie rozporządzenia w sprawie sposobu podziału czę-

7 W dokumentach źródłowych można się spotkać z określeniem tej części jako części "za uczestnictwo w zajęciach".

8 W dokumentach źródłowych można się spotkać z określeniem tej części jako części „za efekt”.

9 Zob. Projekt ustawy o finasowaniu zadań oświatowych. Ocena skutków regulacji, s. 5, https://legislacja.rcl.gov.pl/docs//2/12298908/12436004/12436005/dokument307704. pdf. 
ści oświatowej subwencji ogólnej dla jednostek samorządu terytorialnego w roku $2018^{10}$. W konsekwencji podziału dotychczasowej subwencji oświatowej naliczanej na uczniów poszczególnych rodzajów szkół kształcących dorosłych na dwie części: „za uczestnictwo w zajęciach” oraz „za zdany egzamin”, do algorytmu podziału części oświatowej proponuje się dodać nową wagę „za zdany egzamin” dla:

- uczniów w liceach ogólnokształcących dla dorosłych, którzy zdali egzamin maturalny,

- uczniów w szkołach policealnych (wszystkie kategorie uczniów, bez szkół specjalnych), którzy zdali egzaminy potwierdzające wszystkie kwalifikacje w danym zawodzie,

- uczestników kwalifikacyjnych kursów zawodowych, którzy zdali egzamin potwierdzający kwalifikacje w zawodzie w zakresie danej kwalifikacji.

Wartość wagi kształtuje się na poziomie 0,165 , co wyniesie w przybliżeniu około 890 zł na ucznia. Wagą „za zdany egzamin” zostaną przeliczeni uczniowie, którzy zdali egzamin w ubiegłym roku szkolnym (czyli waga będzie uwzględniać zdawalność z rocznym opóźnieniem).

Należy zauważyć, że finansowanie „za efekt” nie zostało ograniczone tylko do szkół „niesamorządowych”, ale również objęło szkoły prowadzone przez jednostki samorządu terytorialnego, dotyczy bowiem m.in. uczniów liceów ogólnokształcących dla dorosłych, którzy uzyskali świadectwo dojrzałości, oraz uczniów szkół policealnych niebędących szkołami specjalnymi, którzy uzyskali dyplom potwierdzający kwalifikacje zawodowe (z wyłączeniem uczniów niepełnosprawnych) bez względu na organ prowadzący te szkoły ${ }^{11}$.

Konsekwencją podziału dotacji na dwie części są również planowane w projekcie rozporządzenia w sprawie sposobu podziału części oświatowej w roku 2018 zmiany poziomu subwencji „za uczestnictwo w zajęciach”, polegające m.in. na zmniejszeniu wraz ze zróżnicowaniem wskaźników do wyliczenia kwot subwencji dla liceów ogólnokształcących dla dorosłych oraz szkół policealnych w czę-

10 Zob. https://legislacja.rcl.gov.pl/projekt/12304953/katalog/12469922\#12469922.

11 Zob. definicja wagi $\mathrm{P}_{11}=0,165 \mathrm{w}$ Projekcie rozporzadzenia Ministra Edukacji Narodowej w sprawie sposobu podziału części oświatowej subwencji ogólnej dla jednostek samorządu terytorialnego $w$ roku 2018, https://legislacja.rcl.gov.pl/projekt/12304953/ katalog/12469916\#124699160:

$P_{11}=0,165$ - dla uczniów liceów ogólnokształcących dla dorosłych, którzy uzyskali świadectwo dojrzałości, dla uczniów szkół policealnych niebędących szkołami specjalnymi, którzy uzyskali dyplom potwierdzający kwalifikacje zawodowe (z wyłaczeniem uczniów niepetnosprawnych), dla uczestników kwalifikacyjnych kursów zawodowych prowadzonych przez szkoły lub placówki (z wyłączeniem uczestników kwalifikacyjnych kursów zawodowych prowadzonych przez placówki prowadzone przez osoby prawne inne niż jednostki samorzadu terytorialnego lub przez osoby fizyczne), którzy zdali egzamin potwierdzający kwalifikacje w zawodzie w zakresie danej kwalifikacji. 
ści SOA ${ }^{12}$. Ministerstwo Edukacji Narodowej szacuje, że w rezultacie przyjętych zmian wiążących się ze zmniejszeniem wskaźników w części SOA dla liceów ogólnokształcących dla dorosłych oraz szkół policealnych skutek finansowy wyniesie około 228,5 mln zł (zmiana dotyczy 332 tys. uczniów). Porównanie średnich kwot subwencji na ucznia naliczanych poszczególnymi wskaźnikami prowadzi do wniosku, że w stosunku do roku 2017 relatywnie największy spadek kwot subwencji na ucznia dotyczyć będzie niepublicznych szkół dla dorosłych (zob. tabela 1$)^{13}$.

Tabela 1. Zróżnicowanie wskaźników do wyliczenia kwot subwencji dla liceów ogólnokształcących dla dorosłych oraz szkół policealnych w części SOA

\begin{tabular}{|c|c|c|c|c|c|c|}
\hline \multirow[t]{2}{*}{ Wskaźnik } & \multirow[t]{2}{*}{ Kategorie uczniów } & \multicolumn{2}{|c|}{$\begin{array}{l}\text { Wskaźniki do części } \\
\text { SOA }\end{array}$} & \multicolumn{2}{|c|}{$\begin{array}{l}\text { Średnia kwota } \\
\text { subwencji na } \\
\text { ucznia naliczana } \\
\text { poszczególnymi } \\
\text { wskaźnikami w zł }\end{array}$} & \multirow[t]{2}{*}{$\begin{array}{l}\text { Zmiana } \\
\text { w \% }\end{array}$} \\
\hline & & 2017 r. & $\begin{array}{c}\text { projekt } \\
\text { na } \\
2018 \mathrm{r} .\end{array}$ & 2017 r. & $\begin{array}{c}\text { projekt } \\
\text { na } \\
2018 \mathrm{r} .\end{array}$ & \\
\hline Sf & $\begin{array}{l}\text { Uczniowie publicznych LO i szkół policeal- } \\
\text { nych dla dorosłych (tryb stacjonarny) }\end{array}$ & 0,700 & 0,600 & 3844 & 3295 & 14 \\
\hline $\mathrm{Sg}$ & $\begin{array}{l}\text { Uczniowie niepublicznych szkół policeal- } \\
\text { nych dla dorosłych (tryb zaoczny) }\end{array}$ & 0,180 & 0,06 & 989 & 330 & 67 \\
\hline Sh & $\begin{array}{l}\text { Uczniowie niepublicznych LO dla dorosłych } \\
\text { (tryb zaoczny) }\end{array}$ & 0,180 & 0,1 & 987 & 548 & 44 \\
\hline $\mathrm{Si}$ & $\begin{array}{l}\text { Uczniowie publicznych LO i szkół policeal- } \\
\text { nych dla dorosłych (tryb zaoczny) }\end{array}$ & 0,420 & 0,330 & 2312 & 1816 & 21 \\
\hline Sj & $\begin{array}{l}\text { Uczniowie niepublicznych LO i policeal- } \\
\text { nych szkół dla dorosłych (tryb stacjonarny) }\end{array}$ & 0,350 & 0,250 & 1914 & 1367 & 29 \\
\hline Sk & $\begin{array}{l}\text { Uczniowie publicznych szkół policealnych } \\
\text { dla dzieci i młodzieży }\end{array}$ & 1,000 & 0,900 & 5458 & 4912 & 10 \\
\hline SI & $\begin{array}{l}\text { Uczniowie niepublicznych szkół policeal- } \\
\text { nych dla dzieci i młodzieży }\end{array}$ & 1,000 & 0,450 & 5511 & 2480 & 55 \\
\hline
\end{tabular}

Źródło: Projekt rozporzadzenia Ministra Edukacji Narodowej w sprawie sposobu podziału części oświatowej subwencji ogólnej dla jednostek samorzqdu terytorialnego w roku 2018. Ocena skutków regulacji, https:// legislacja.rcl.gov.pl/projekt/12304953/katalog/12469922\#12469922, s. 5.

W ocenie Ministerstwa Edukacji Narodowej w rezultacie przyjętych rozwiązań w przypadku szkól, które charakteryzują się wysoką zdawalnością, subwencja światowa zostanie naliczona na uczniów tych szkół w wysokości tak jak dotychczas lub nawet wyższej niż do tej pory, natomiast w przypadku uczniów szkół z niską zdawalnością zostanie naliczona subwencja niższa niż do tej pory ${ }^{14}$.

12 Kwota bazowa części oświatowej według finansowego standardu A podziału części oświatowej na realizację zadań szkolnych.

13 Zob. Projekt rozporządzenia Ministra Edukacji Narodowej w sprawie sposobu podziatu części oświatowej subwencji ogólnej dla jednostek samorządu terytorialnego $w$ roku 2018. Uzasadnienie, op. cit., s. 3.

14 Zob. Projekt rozporzadzenia Ministra Edukacji Narodowej w sprawie sposobu podziału części oświatowej subwencji ogólnej dla jednostek samorządu terytorialnego $w$ roku 2018. Uzasadnienie, op. cit., s. 3. 
W kontekście zagadnienia kształcenia w szkołach dla dorosłych należy zwrócić uwagę na wnioski płynące z kontroli przeprowadzonej przez Najwyższą Izbę Kontroli (NIK) w zakresie prawidłowości, skuteczności i efektywności kształcenia w szkołach dla dorosłych ${ }^{15}$. NIK wielokrotnie zwracała uwagę na problem niskiej skuteczności kształcenia dorosłych. Już w 2008 r. negatywnie oceniła funkcjonowanie szkół niepublicznych o uprawnieniach szkół publicznych dla dorosłych w związku ze stwierdzeniem istotnych nieprawidłowości w organizacji tych szkół, skutkujących niską efektywnością kształcenia, którą wyrażał niewielki odsetek słuchaczy promowanych i kończących wspomniane szkoły. Wskazywano wówczas m.in., że w celu wyeliminowania stwierdzonych nieprawidłowości Minister Edukacji Narodowej powinien opracować mechanizmy prawne, uniemożliwiające uzyskiwanie dotacji przez szkoły niepubliczne w nadmiernej wysokości, a także uzyskiwanie uprawnień szkół publicznych przez szkoły, których efektywność kształcenia jest niezadowalająca. Z kolei w 2012 r. NIK proponowała podjęcie działań w celu wprowadzenia zmiany ustawowego sposobu obliczania dotacji dla niepublicznych szkół, w których nie jest realizowany obowiązek szkolny lub obowiązek nauki (czyli m.in. szkół dla dorosłych). Uwagi i wnioski sformułowane dotychczas przez NIK w kontrolowanym zakresie nadal pozostają aktualne. Mimo wprowadzenia pewnych zmian, które miały wyeliminować lub ograniczyć występujące patologie w zakresie m.in. pozyskiwania dotacji z budżetu jednostek samorządu terytorialnego, kształcenie dorosłych pozostaje wciąż obszarem w znacznym stopniu obciążonym nieprawidłowościami. Zdaniem NIK główne zmiany, które należy zastosować, powinny doprowadzić do uzależnienia udzielania lub ustalania wysokości wypłacanej dotacji od efektu kształcenia. Rozwiązania te mogłyby być oparte na zasadach, jakie funkcjonują w przypadku finansowania kwalifikacyjnych kursów zawodowych - w tym wypadku wypłata dotacji następuje dopiero po zdaniu przez słuchacza egzaminu potwierdzającego kwalifikacje w zawodzie ${ }^{16}$. NIK w rezultacie przeprowadzonej kontroli wniosła o rozważenie przez Ministra Edukacji Narodowej przygotowania zmian obowiązujących przepisów w zakresie dotowania szkół niepublicznych. Pożądaną jakość kształcenia można byłoby osiągnąć, uzależniając udzielanie dotacji lub jej wysokość od skuteczności i uzyskiwanych efektów kształcenia. NIK zaproponowała również, aby podstawę obliczania dotacji stanowiły odpowiednie kwoty przewidziane na jednego ucznia danego typu i rodzaju szkoły w części oświatowej subwencji ogólnej otrzymywanej przez jednostki samorządu terytorialnego ${ }^{17}$.

15 Zob. Najwyższa Izba Kontroli, Informacja o wynikach kontroli. Kształcenie w szkołach dla dorostych, 2017, https://www.nik.gov.pl.

16 Ibidem, s. 17.

17 Ibidem, s. 18. Informacja NIK o wynikach kontroli w sprawie kształcenia w szkołach dla dorosłych jest datowana na 16 sierpnia 2017 r., tj. przed wpłynięciem do Sejmu projektu ustawy o finansowaniu zadań oświatowych, który uwzględnia powyższy postulat. 
Omawiając finansowanie szkół dla dorosłych, NIK stwierdza, że: Minister Edukacji Narodowej poinformowat, że w rozporzadzeniu z 22 grudnia 2016 r. w sprawie sposobu podziału części oświatowej subwencji ogólnej dla jednostek samorzadu terytorialnego $w$ roku 2017 dokonano zmiany zasad subwencjonowania słuchaczy szkół dla dorosłych kształcacych się w trybie zaocznym. Zmiana ta jest kontynuacja rozwiazania zaproponowanego na rok 2015, kiedy to dla stuchaczy szkół dla dorosłych kształcących się $w$ trybie zaocznym obniżono wartości wskaźników z 0,7 na 0,5 (szkoły publiczne) i z 0,35 na 0,25 (szkoły niepubliczne). Planowano wtedy, że w kolejnym roku wartość wskaźników powinna ulec dalszemu obniżeniu. Na rok 2017 wprowadzono niższe wskaźniki, tj. w przypadku publicznych szkół dla dorosłych kształcacych $w$ trybie zaocznym obniżono wskaźniki $z$ 0,5 do 0,42, a dla niepublicznych z 0,25 na 0,18. W piśmie wskazano też: warto zauważyć dysproporcję pomiędzy środkami naliczonymi w subwencji oświatowej na uczniów szkół prowadzonych przez podmioty inne niż jst [jednostki samorządu terytorialnego - dopisek H.D.] (liceów ogólnokształcących oraz szkół zawodowych) a wysokościa dotacji udzielonych tym szkołom. W 2015 r. dotacje udzielone przez powiaty liceom ogólnokształcącym stanowiły 85,5\% naliczonej na uczniów tych szkół kwoty subwencji, a w przypadku szkół zawodowych było to tylko $60,1 \%{ }^{18}$.

W ramach ustaleń poczynionych przez NIK w toku kontroli w sprawie kształcenia w szkołach dla dorosłych zwraca uwagę opinia dyrektorów szkół dla dorosłych odnośnie do obniżenia kwoty dotacji. Część z nich, negatywnie oceniając te obniżenia, wskazywała na liczne konsekwencje tego zjawiska. Najczęściej ankietowani dyrektorzy podnosili, że taki stan rzeczy skutkował przede wszystkim brakiem zakupu pomocy naukowych i dydaktycznych, podwyżek dla nauczycieli (ewentualnie zmniejszeniem ich wynagrodzeń). Ponadto wskazywano na ograniczenie liczby zajęć dodatkowych, wynajmowanych pomieszczeń czy oferty nauczania ${ }^{19}$.

Dokonując analizy prawnofinansowej wprowadzanych rozwiązań w odniesieniu do publicznych szkół policealnych (oraz innych szkół dla dorosłych) prowadzonych przez podmioty inne niż jednostki samorządu terytorialnego, należy stwierdzić, że przewidują one faktycznie znaczne obniżenie wysokości otrzymywanych przez te podmioty kwot dotacji, w stosunku do dotychczasowego poziomu, co może istotnie wpływać na działalność przynajmniej części szkół policealnych (dla dorosłych).

Uzasadniając powyższe, trzeba zwrócić uwagę na następujące uwarunkowania:

- Nowy system dotacji zakłada uzależnienie przyznania jej części „dodatkowej” od wskaźnika zdawalności w danej placówce, przy czym do oceny skutków regulacji przyjęto arbitralnie i bez szczegółowego uzasadnienia, że wskaźniki te będą w poszczególnych kategoriach szkół dla dorosłych istotnie wzra-

\footnotetext{
$18 \quad$ Ibidem, s. 36.

19 Ibidem, s. 41.
} 
stać, co z kolei ma spowodować brak odczuwalnego zmniejszenia wysokości dotacji. I tak w przypadku liceów ogólnokształcących dla dorosłych wzrost zdawalności ma wynieść ponad 50\% (z 9,5\% do 15\% zdających), natomiast w szkołach policealnych o blisko $20 \%$ (z $42 \%$ do $50 \%$ zdających) ${ }^{20}$. Zatem z uwagi na powiązanie wysokości części dotacji z podwyższonymi wskaźnikami zdawalności, które mogą być niesłychanie trudne do zrealizowania przez placówki oświatowe prowadzone przez osoby prawne niebędące jednostkami samorządu terytorialnego lub osoby fizyczne, można oczekiwać, że przynajmniej dla części placówek faktyczna wysokość części „dodatkowej”/ „za efekt” dotacji może być poważnie niższa od zakładanej przez twórców nowelizacji, co z kolei może wpłynąć negatywnie na możliwość realizacji przez niesamorządowe placówki oświatowe działalności edukacyjnej.

- Również sami twórcy ustawy o finansowaniu zadań oświatowych wprost wskazali, że zmiany w systemie finansowania publicznych szkół dla dorosłych będą skutkować oszczędnościami, sięgającymi w roku 2018 kwoty $48580200 \mathrm{zl}$, w roku 2019 kwoty 51311223 zł, natomiast w roku 2020 i latach następnych kwoty $56773269 \mathrm{zł}^{21}$. Jednocześnie przyjęto, że kwota subwencji oświatowej na jednego ucznia w odniesieniu do publicznych szkół policealnych (takich jak Publiczna Zaoczna Policealna Szkoła Informatyki Cosinus) po zmianie systemu ulegnie zmniejszeniu o 19\% - z kwoty 5892 zł do kwoty $4787 \mathrm{zł}^{22}$. Projektodawca przewidział również, że środki uzyskane $\mathrm{z}$ wprowadzenia zmian $\mathrm{w}$ zakresie dotacji: zostana przeznaczone na sfinansowanie zwiększonej liczby godzin wynikających z nowych ramowych planów nauczania [oraz] będa adresowane dla małych szkót podstawowych ${ }^{23}$.

Jak zatem wynika z powyższego, istotną intencją projektodawców związaną z wdrożeniem nowego systemu dotacji dla publicznych szkół dla dorosłych (w tym szkół policealnych) było uzyskanie oszczędności, które z kolei po stronie owych szkół oznaczają istotne ograniczenie uzyskiwanych sum dotacji, które z całą pewnością mogą przynajmniej częściowo ujemnie wpływać na funkcjonowanie tego typu placówek.

W kontekście nakreślonych wyżej celów projektodawców ustawy o finansowaniu zadań oświatowych oraz projektu rozporządzenia Ministra Edukacji Narodowej w sprawie sposobu podziału części oświatowej subwencji ogólnej dla jednostek samorządu terytorialnego w roku 2018 związanych z ograniczeniem wydatków na dotacje, należy odnotować, że: [i]ntencja ustawodawcy jest dotowa-

20 Projekt ustawy o finansowaniu zadań oświatowych. Ocena skutków regulacji, op. cit., s. 5-6.

$21 \quad$ Ibidem, s. 5.

22 Ibidem, s. 6.

23 Ibidem, s. 6-7. 
nie szkół publicznych niesamorządowych w takiej samej kwocie na ucznia jak wydatki na ucznia ponoszone przez samorzad w szkołach samorzadowych. Natomiast szkół niepublicznych w kwocie niższej ${ }^{24}$.

Urzeczywistnienie tego zamiaru zależeć jednak będzie w dużej mierze od skuteczności kształcenia w szkołach dla dorosłych prowadzonych przez osoby prawne niebędące jednostkami samorządu terytorialnego lub osoby fizyczne. Warto w tym miejscu zwrócić uwagę, że NIK ustaliła, że wskaźniki zdawalności zarówno egzaminu maturalnego, jak i egzaminów potwierdzających kwalifikacje w zawodzie w publicznych szkołach dla dorosłych były znacznie wyższe niż w szkołach niepublicznych ${ }^{25}$. Jak zauważa NIK w syntezie wyników kontroli poświęconej kształceniu w szkołach dla dorosłych: [w] MEN nie prowadzono pogłębionych analiz dotyczących skuteczności kształcenia w szkołach dla dorosłych. Analiz zdawalności egzaminów zewnętrznych $w$ szkołach dla dorosłych nie prowadziła także CKE oraz okregowe komisje egzaminacyjne. Przeprowadzone przez NIK, na podstawie danych uzyskanych ze wszystkich OKE $w$ kraju badanie wskazuje, że zdawalność egzaminów potwierdzajacych kwalifikacje w zawodzie $w$ szkołach dla dorosłych jest istotnie (o kilka punktów procentowych) gorsza, niż ogólna zdawalność tych egzaminów we wszystkich typach szkót. Zdawalność egzaminów zewnętrznych jest wyższa w szkołach publicznych. Różnica w poziomie zdawalności egzaminów kwalifikacyjnych w publicznych i niepublicznych szkołach policealnych wynosiła w latach 2014, 2015 i 2016 odpowiednio: 12,6; 13,5 oraz 10,8 punktu procentowego. W liceach ogólnokształcących dla dorosłych różnica między $z$ dawalnościa $w$ szkołach publicznych $i$ niepublicznych wynosiła $w$ tym okresie średnio 4,3 punktu procentowego dla języka polskiego, 3 punkty procentowe dla matematyki oraz 4,5 punktu procentowego dla języka angielskiego na korzyść szkót publicznych ${ }^{26}$.

Zgodnie z obowiązującymi regulacjami ustawy o systemie oświaty prowadzone przez osoby prawne niebędące jednostkami samorządu terytorialnego lub osoby fizyczne publiczne szkoły, w których nie jest realizowany obowiązek szkolny lub obowiązek nauki, otrzymują na każdego ucznia dotację z budżetu jednostki samorządu terytorialnego obowiązanej do prowadzenia danego typu i rodzaju szkół w wysokości równej podstawowej kwocie dotacji dla szkół danego typu i rodzaju, nie niższej jednak niż kwota przewidziana na takiego ucznia w części oświatowej subwencji ogólnej dla jednostki samorządu terytorialnego. Przy tym przez podstawową kwotę dotacji dla szkół danego typu i rodzaju należy

24 Zob. Raport z konsultacji dotyczący projektu ustawy o finansowaniu zadań oświatowych, sporzadzony $w$ dniu 11 sierpnia 2017 r., https://legislacja.rcl.gov.pl/docs//2/122 98908/12436004/12436005/dokument307709.pdf.

25 Zob. Najwyższa Izba Kontroli, Informacja o wynikach kontroli. Kształcenie w szkołach dla dorostych, op. cit., s. 11.

26 Ibidem, s. 13. 
rozumieć kwotę wydatków bieżących zaplanowanych na prowadzenie przez jednostkę samorządu terytorialnego szkół danego typu i rodzaju, z uwzględnieniem ewentualnie określonych pomniejszeń wskazanych w przepisach (art. 78b ust. 3 ustawy o systemie oświaty). W razie braku na terenie odpowiednio gminy lub powiatu szkoły danego typu i rodzaju prowadzonej odpowiednio przez gminę lub powiat kwotę dotacji określa się w wysokości nie niższej niż kwota przewidziana na takiego ucznia w części oświatowej subwencji ogólnej odpowiednio dla gminy lub powiatu.

Mankamentem obowiązujących dotychczas regulacji jest odniesienie do rodzaju szkoły. Z uwagi na brak definicji rodzaju szkoły samorząd musi samodzielnie określić rodzaj dotowanej szkoły, biorąc pod uwagę różne czynniki (przykładowo: położenie szkoły na terenie wsi lub miasta, tryb nauki, realizację obowiązku szkolnego lub nauki, kategorię uczniów, czy szkoła jest szkołą specjalną, procentowy udział oddziałów: integracyjnych, sportowych, mistrzostwa sportowego, dwujęzycznych, dla mniejszości, międzynarodowych, terapeutycznych, czy szkoła jest szkołą zawodową, czy jest szkołą artystyczną itp.). W praktyce określenie rodzaju szkoły polega na wyznaczeniu odpowiedniej kombinacji powyższych czynników dla każdej dotowanej szkoły, a przy braku jednoznacznej definicji stwarza istotne problemy. Następnie jednostka samorządu terytorialnego określa, czy prowadzi dokładnie taki typ i rodzaj szkoły jak szkoła dotowana. Jeżeli tak, to, aby obliczyć wysokość dotacji, samorząd musi dla każdego typu i rodzaju dotowanej szkoły oddzielnie określić wysokość zaplanowanych w budżecie wydatków bieżących na prowadzenie dokładnie takiego typu i rodzaju szkoły. Natomiast jeżeli samorząd nie prowadzi szkoły takiego typu i rodzaju jak szkoła dotowana, to musi wyznaczyć najbliższą jednostkę samorządu terytorialnego prowadzącą taki typ i rodzaj szkoły - najpierw wśród samorządów graniczących, potem $\mathrm{w}$ powiecie, $\mathrm{w}$ województwie, a na końcu na terenie całego $\mathrm{kraju}^{27}$.

Procedura taka stwarza jednak istotne problemy przy ustalaniu kwot dotacji dla szkół danego typu i rodzaju, stąd w projekcie ustawy o finansowaniu zadań oświatowych zaproponowano zmiany polegające na tym, aby w przypadku szkół publicznych, w których nie jest realizowany obowiązek szkolny lub obowiązek nauki, dotacja określana była na każdego ucznia w wysokości równej kwocie przewidzianej w części oświatowej subwencji ogólnej dla jednostki samorządu terytorialnego na takiego ucznia i przemnażana dodatkowo przez wskaźnik zwiększający dla szkół danego typu. Ostatecznie przyjęte przez Sejm oraz przez Senat brzmienie art. 25 ust. 3 ustawy o finansowaniu zadań oświatowych w sposób istotny różni się od tego, które zostało przewidziane w pierwotnym projekcie ustawy (i do którego przygotowano uzasadnienie oraz ocenę skutków regulacji, a także raport z konsultacji). W przyjętej przez Sejm RP i Senat RP wersji ustawy

${ }_{27}$ Zob. Projekt ustawy o finansowaniu zadań oświatowych. Uzasadnienie, op. cit., s. 8. 
z 27 października 2017 r. w treści art. 25 ust. 3 usunięto zapis mówiący o stosowaniu wskaźnika zwiększającego, co oznacza, że kwota dotacji ograniczona jest jedynie do kwoty przewidzianej na ucznia w części oświatowej subwencji ogólnej dla jednostki samorządu terytorialnego.

Tymczasem w uzasadnieniu do projektu ustawy wskazywano, że: [w]prowadzenie powyższego wskaźnika jest konieczne, aby w przypadku dotowanych szkót publicznych, odpowiednio zwiększyć kwotę przeznaczona w części oświatowej subwencji ogólnej dla jednostki samorządu terytorialnego na ucznia, uwzględniając wszystkie wydatki ponoszone przez ten samorzad na szkoły danego typu ${ }^{28}$.

Zatem na podstawie pierwotnego brzmienia przepisu dotacja przeznaczona dla publicznej szkoły niesamorządowej miała ulegać faktycznemu podwyższeniu według wskaźnika zwiększającego. Na istotną funkcję owego wskaźnika zwrócono również uwagę na s. 10 Raportu z konsultacji dotyczacego projektu ustawy, wydanego w dniu 11 sierpnia 2017 r., w którym podkreślono, że: [n]atomiast w przypadku szkół publicznych kwota w subwencji oświatowej zostanie odpowiednio zwiększona przez przemnożenie jej przez tzw. wskaźnik zwiększajacy. Wskaźnik zwiększający uwzględnia rzeczywiste wydatki danego samorzadu na dany typ szkoły poprzez określenie, jaki procent dany samorzad wydaje ponad subwencje (tj. iloraz rzeczywistych poniesionych wydatków $w$ danym samorządzie na dany typ szkoły do kwoty subwencji otrzymanej na te szkoły). Przemnożenie kwoty subwencji przez wskaźnik zwiększający umożliwi więc odniesienie kwoty dotacji do rzeczywistych wydatków ponoszonych przez samorząd na dany typ szkoły ${ }^{29}$.

Z powyższych ustaleń wynika zatem, że uwzględnianie wskaźnika zwiększającego, uregulowanego $\mathrm{w}$ art. 14 ust. 1 i 2 projektu ustawy (a pominiętego w samej ustawie), biorącego pod uwagę rzeczywiste wydatki samorządu, miało stanowić swoisty wentyl bezpieczeństwa systemu, który gwarantował równe zasady finansowania oświatowych jednostek samorządowych oraz pozostałych publicznych placówek otrzymujących dotacje.

Usunięcie w treści art. 25 ust. 3 zapisu mówiącego o stosowaniu wskaźnika zwiększającego oznacza, że kwota dotacji ograniczona jest jedynie do kwoty przewidzianej na ucznia w części oświatowej subwencji ogólnej dla jednostki samorządu terytorialnego. Tym samym w obecnych uwarunkowaniach prawnych nie zostały uwzględnione postulaty samego projektodawcy, który uznawał za konieczne wprowadzenie owego wskaźnika zwiększającego. Rezygnacja z pierwotnej wersji przepisu art. 25 ust. 3 ustawy może zatem skutkować tym, że faktycznie uzyskane przez publiczne szkoły niesamorządowe kwoty dotacji będą inne niż zakładane w projekcie ustawy, jego uzasadnieniu oraz w przyjętej ocenie

28 Zob. Uzasadnienie do projektu ustawy o finansowaniu zadań oświatowych, s. 8, https:// legislacja.rcl.gov.pl/docs//2/12298908/12436004/12436005/dokument307702.pdf.

29 Https://legislacja.rcl.gov.pl/docs//2/12298908/12436004/12436005/dokument307709.pdf. 
skutków regulacji. Nie ma pewności, czy w skutek uchwalonych przez parlament przepisów art. 25 ustawy o finansowaniu zadań oświatowych publiczne szkoły prowadzone przez osoby prawne niebędące jednostkami samorządu terytorialnego oraz osoby fizyczne, w których nie jest realizowany obowiązek szkolny lub obowiązek nauki, otrzymują na każdego ucznia dotację z budżetu w kwocie równej wysokości tej dotacji, którą otrzymałyby zgodnie z dotychczas obowiązującymi rozwiązaniami. Wydaje się, że uzależnione to jest od tego, na ile subwencja oświatowa odwzorowuje specyfikę ekonomiczną szkół.

\section{Podsumowanie}

- W konsekwencji rozwiązania przewidzianego w art. 25 ustawy o finansowaniu zadań oświatowych oraz rozwiązań planowanych na poziomie rozporządzenia w sprawie sposobu podziału części oświatowej subwencji ogólnej dla jednostek samorządu terytorialnego w roku 2018 dotychczasowa subwencja naliczana na uczniów poszczególnych rodzajów szkół (w tym licea ogólnokształcące dla dorosłych, szkoły policealne) została podzielona na dwie części: „za uczestnictwo w zajęciach”, która ma charakter bezwarunkowy, i „za zdany egzamin", która ma charakter warunkowy i zależy od efektywności kształcenia. W rezultacie tych zmian kwota dotacji udzielanej szkołom dla dorosłych prowadzonym przez osoby prawne niebędące jednostkami samorządu terytorialnego oraz osoby fizyczne w części będzie uzależniona od skuteczności i uzyskiwanych efektów kształcenia. O taką zmianę przepisów w zakresie dotowania szkół niepublicznych wnioskowała Najwyższa Izba Kontroli. Według projektowanego algorytmu podziału części oświatowej subwencji ogólnej dla jednostek samorządu terytorialnego na rok 2018 finansowanie „za efekt" dotyczy w takim samym stopniu szkół niesamorządowych co szkół prowadzonych przez jednostki samorządu terytorialnego.

Zakłada się, że w rezultacie przyjętych rozwiązań w szkołach, które charakteryzują się wysoką zdawalnością, subwencja zostanie naliczona na uczniów tych szkół w wysokości tak jak dotychczas lub nawet wyższej, natomiast w szkołach z niską zdawalnością zostanie naliczona subwencja niższa niż do tej pory.

Konsekwencją wydzielenia w subwencji oświatowej części „za zdany egzamin” są zmiany poziomu subwencji „za uczestnictwo w zajęciach”. Udział subwencji w części „za uczestnictwo w zajęciach” do dotychczasowej subwencji został ustalony w zależności od trybu kształcenia i kategorii uczestników tego kształcenia, a nie ze względu na organ prowadzący. Ze zmianami w subwencji oświatowej w części „za uczestnictwo w zajęciach” wiąże się przyjęte w projekcie rozporządzenia w sprawie sposobu podziału części oświatowej subwencji ogólnej dla jednostek samorządu terytorialnego w roku 2018 zmniejszenie 
wskaźników do wyliczenia kwot subwencji dla liceów ogólnokształcących dla dorosłych oraz szkół policealnych, które dotyczą w tym samym stopniu szkół niesamorządowych co szkół prowadzonych przez jednostki samorządu terytorialnego.

$\mathrm{W}$ świetle powyższego można stwierdzić, że z prawnofinansowego punktu widzenia faktycznie może dojść do nawet znacznego obniżenia kwot subwencji naliczanych na uczniów szkół dla dorosłych w stosunku do dotychczasowego poziomu, co może w sposób istotny wpływać na funkcjonowanie szkół dla dorosłych.

- Dotychczas funkcjonujące zasady dotowania publicznych szkół dla dorosłych prowadzonych przez osoby prawne niebędące jednostkami samorządu terytorialnego lub osoby fizyczne przewidują dotację z budżetu jednostki samorządu terytorialnego obowiązanej do prowadzenia danego typu i rodzaju szkół w wysokości równej podstawowej kwocie dotacji dla szkół danego typu i rodzaju, nie niższej jednak niż kwota przewidziana na takiego ucznia w części oświatowej subwencji ogólnej dla jednostki samorządu terytorialnego. Dotychczas funkcjonujący system zakładał więc konieczność równego traktowania szkół niesamorządowych oraz szkół prowadzonych przez jednostki samorządu terytorialnego ${ }^{30}$.

Przyjęte nowe przepisy w tym zakresie (art. 25 ustawy o finansowaniu zadań oświatowych) wprowadzają zmiany powodujące, że w szkołach prowadzonych przez osoby prawne niebędące jednostkami samorządu terytorialnego oraz osoby fizyczne publiczne szkoły, w których nie jest realizowany obowiązek szkolny lub obowiązek nauki, niebędące szkołami specjalnymi, dotacja określana będzie na każdego ucznia w wysokości równej kwocie przewidzianej na takiego ucznia w części oświatowej subwencji ogólnej dla jednostki samorządu terytorialnego. W przeciwieństwie do prowadzonych przez osoby prawne niebędące jednostkami samorządu terytorialnego oraz osoby fizyczne publicznych szkół, w których jest realizowany obowiązek szkolny lub obowiązek nauki, dotacje dla szkół, w których nie jest realizowany obowiązek szkolny lub obowiązek nauki, nie będą przemnażane dodatkowo przez wskaźnik zwiększający dla szkół danego typu. Jakkolwiek w projekcie ustawy o finansowaniu zadań oświatowych zasadę przemnażania dotacji o wskaźnik zwiększający przyjęto również w stosunku do szkół, w których nie jest realizowany obowiązek szkolny lub obowiązek nauki, a w uzasadnieniu do tego projektu argumentowano, że wprowadzenie wskaźnika jest konieczne, aby w przypadku dotowanych szkół publicznych odpowiednio zwiększyć kwotę przeznaczoną w części oświatowej subwencji ogólnej dla jednostki samorzą-

30 Zob. również wyroki: NSA z 8 lutego 2013 r., sygn. akt II GSK 2095/11, LEX nr 1358351, oraz WSA w Kielcach z 25 kwietnia 2013 r., sygn. akt II SA/Ke 215/13, LEX nr 1325744. 
du terytorialnego na ucznia, uwzględniając wszystkie wydatki ponoszone przez ten samorząd na szkoły danego typu (ponad kwotę naliczaną w części oświatowej subwencji ogólnej). Nie ma jasności co do tego, czy brak przemnożenia dotacji wskaźnikiem zwiększającym wpłynie na odwzorowanie w kwocie dotacji kosztów utrzymania szkół prowadzonych przez jednostki samorządu terytorialnego. W tym kontekście może budzić wątpliwości, czy niezastosowanie wskaźnika zwiększającego kwoty części oświatowej subwencji ogólnej w przypadku prowadzonych przez osoby prawne niebędące jednostkami samorządu terytorialnego oraz osoby fizyczne szkół publicznych, w których nie jest realizowany obowiązek szkolny lub obowiązek nauki, nie spowoduje istotnych różnic $\mathrm{w}$ wysokości dotacji w stosunku do obecnych kwot dotacji. Jeśli nowe rozwiązanie nie byłoby neutralne dla dotowanych placówek, to może dochodzić do naruszenia reguły równego traktowania podmiotów prowadzących placówki oświatowe.

\section{Bibliografia}

Najwyższa Izba Kontroli, Informacja o wynikach kontroli. Kształcenie w szkołach dla dorostych, 2017, https://www.nik.gov.pl.

Pilich M., Ustawa o systemie oświaty. Komentarz, 2015, LEX, komentarz do art. 80.

Pirożyński Z., Budżetowanie brutto [w:] Leksykon finansowo-bankowy, red. W. Jaworski, Warszawa 1991. 